\title{
The Strategy Focuses of Recreation and Tourism Activities of Ichnia National Nature Park (Ukraine) Design Employing Canvas Business- model and SWOT-analysis
}

\author{
Viktoriia Kiptenko $^{1 *}$, and Tetiana Mykhailenko ${ }^{2}$ \\ 1,2Department of Regional Studies and Tourism, the Faculty of Geography, National University of \\ Kyiv named after Taras Shevchenko, 64/13 Volodymyrska str., Kyiv, 01601, Ukraine
}

\begin{abstract}
National parks across the world contribute to the preservation of biodiversity, playing simultaneously an outstanding role in sustainable activities, recreation and tourism in particular. Experience with COVID-19 shows that resilience is fundamental to the sustainability of protected area visitation, which was affected in different ways by pandemics. The last decade challenges for the national nature parks of Ukraine, positive impetuses of several successful projects, enhancement of the community role in the environmental issues caused the search for a framing of the strategy of recreation and tourism activity of the national nature park located in Ichnia, Chernihiv oblast, Ukraine. By employing the Canvas business model and SWOT analysis the client-oriented shift in the above park strategy focuses ground prospects for facts-based decision-making and planning. The focuses advised include restructuring of the organizational patterns of the entity; modernisation of information and communication activities; profiling of demand and diversification of values for travellers of different motivation; networking with stakeholders. Keywords: Recreation, Tourism Activities, Ichnia National Nature Park, Canvas Business-model, SWOTanalysis.
\end{abstract}

\section{Introduction}

Worldwide national parks have furnished models for biodiversity preservation involving sustainable tourism development and provided a blueprint to follow. In particular, frames of destination stewardship arm national park keepers with means to manage nature conservation with the needs of local people and tourists alike [1].

COVID-19 affected protected areas tourism in different ways, including the crucial decline of visitation, just starting to recover; rather slow and not straightforward economic recovery; internalisation of safety considerations into tourist management; examples of online ways of sharing nature; emerging innovations in ways of tourist-dependent communities support; creating stronger alternative revenue streams in tourism destinations

* Corresponding author: kipavika@gmail.com 
by product diversification and innovations; gradual adaptation of travel and tourism market to the new circumstances [2].

For decades, the national nature parks (NNP) of Ukraine faced different problems inhibiting their potential for conventional environmental activities and development of nature recreation and tourism [3,4]. Protected areas like Gorgany reserve, Carpathian Biosphere reserve enjoyed the support of international aid and grants, which are still not enough for over 50 NNPs in the country. They mostly suffer from a lack of public funding, inability to arrange for revenues streams by themselves and improper - often outdated soviet style of management.

The Ichnia NNP's, (situated in Chernihiv oblast, management) - in an attempt to innovate outdated methods of operation - enquired about the possibility to recast its strategy, searching, in particular, for ways to enrich its revenue streams by new vision and approach to recreation and tourism activities relevant to the environmental mission of this protected area.

Thus, we aimed our research on designing the strategy focuses for Ichnia NNP recreation and tourism activities. We speculated the relevance of employing the CANVAS business model and SWOT analysis to provide for a coherent vision of the state-of-art situation and substantiation of the client-oriented focuses for further decision-making and planning.

This study used both secondary and primary data. The secondary sources included legislative documents; reports and informational bulletins of Ichnia NNP; strategies of development for Chernihiv oblast, Ichnia and Parafievka united territorial communities (where the entity is located); relevant academic papers, and open-access information. We collected primary data through observations, field trips, semi-structured interviews with Ichnia NNP's management, as well as a micro-questionnaire of potential visitors/tourists.

Based on content analysis of available secondary sources and primary data exploration we designed the Canvas template to grasp the state-of-art of recreation and tourism activities of the park. We further applied the SWOT-analysis in order to articulate the strategic focuses for recreation and tourism activities decision-making and planning by Ichnia NNP's management.

Being aware that the results of this single case study has limited potential for generalisation, we believe that this example overcomes a lack of previous research discussing the business model of national nature parks and serve similar situations, in which the visualisation of the state-of-arts will help to frame strategic focuses, decision-making and planning of development to be supported by further monitoring and analysis of NPPs activities.

\section{Results and discussion}

\subsection{Employment of Canvas business model and SWOT analysis fit the needs of Ichnia NPP's}

The majority of NNPs of Ukraine, Ichnia NPP in particular, faces various problems on its way to improve the quality and the efficiency of operation. The challenges include illegal land spots invasions, poaching and illegal logging, irregular mosaic land use added by several authorities' initiatives on infrastructure that destroys protected areas, improper management aggravated by poor staff wages, unregulated activities and devastation of national nature parks in occupied Eastern parts of the country and the annexed Crimea, etc. [3,4].

The key possible solutions foresee the improvement of legal, organizational and economic activities in line with sustainable development grounds to increase the competitiveness of the tourism product and the quality of services offered by the national 
parks, which are basically publicly funded in Ukraine $[5,6,7]$. In the above sense, the prospects for the development of environmental-friendly tourism in NPPs has to follow the principles of ecological awareness, focus on nature, preservation of the pristine environment and the local socio-cultural heritage; economic efficiency and sustainable development of the areas where the tours take place [7]. That is why the provision of these principles and the implementation of various strategies could be based on experience, which demonstrates the high competitiveness of national parks having revenue streams from recreation and tourism activities $[8,9]$.

Considering that the business model has an important role in an entity's strategy and explains how their activities operate jointly to implement their strategy, we followed the notion that the business model was studied as a potential tool at various levels of the product, for business units, companies, and industries involved in nature tourism [10]. In addition, broadly used in business and management the business-model concept interpreted through sustainability concerns can be used to achieve the triple-bottom result of short- and long-term perspectives essential for the NPP: economic, social and environmental [10,11].

The Canvas business model is uncommon for nature recreation and tourism research. Most often, this model suggests new opportunities for tourism business management, ways of strengthening competitive positions and core values for other types of tourism: diving [12], sports $[13,14]$, beach [15] and sailing [16], creative [17], as well as to create a tourist city branding [18].

We consider the opinion that Canvas is only a tool that enables firms to articulate their business model [19] advantages Ichnia NNP's administration which lacks appropriate experience. The visualising potential of Canvas' nine blocks [20] - consumer segments, key values, customer relationships, distribution/channels, key resources, key activities, key partnerships, cost structures, and revenue stream - fits the enquiry of Ichnia NNP to clientoriented shift in their recreation and tourism activities to create revenue streams. It is the key values that underlie this model, form a priority in this model and factor customers attraction [19].

SWOT-analysis allows to overcome the critics against static reflections of the situation by Canvas business model and helps to obtain several alternative strategies [21]. By identifying the strengths and weaknesses of the NNP, assessing strategy through opportunities and taking into account threats, we synthesised the relationship between "internal" (strengths and weaknesses) and "external" (opportunities and threats) factors. The formation of a matrix of opportunities and threats with their subsequent ranking - based on the division into three groups according to the probability and degree of influence on the organization of recreational and tourist activities of the NNP allows to characterize the extent to which opportunities promotes strengths, and whether threats do not level a particular strength and the opportunities provided for it. The outcomes shape comparative advantages, challenges and risks that determine the basis for strategic choice - the formulation of strategic objectives for the development of the NNP in the long run.

\subsection{The combined Canvas-SWOT design for Ichnia NPP's recreation and tourism activities shapes the state-of-art and beyond.}

Ichnia NPP was established in 2004 and has a total area of 9665,8 ha; it belongs to the Emerald network.

According to its natural potential, the territory of the park has no alternative in the northern part of the Dnipper left bank forest-steppe. Mostly flat-wavy relief, temperate continental climate with mild winters and warm summers, the Udai and Ichenka rivers, which form a kind of wetlands, numerous ponds and lakes, the richness and value of flora and fauna, preserved in its natural state, contribute to the comfortable conditions for recreation and 
tourism. They provide for environmental and nature-oriented tourism involving walking, excursions (hiking, biking, skiing), boating, mushroom and berry picking, fishing, hunting, etc.

At the same time, climate change in recent years caused increasing arid conditions in the summer. Respectively, hydrological resources lose their recreational attractiveness. Thus, organization of recreational and tourism activities needs consideration and flexibility.

The zone of regulated recreation constitutes $50.5 \%$ of the NNP's territory and the zone of stationary recreation amounts for $1 \%$ of it. More than $50 \%$ of the territory is in permanent use without seizure from land users (Zhadkivske, Kamyanske and Ivanytske forestry). Administratively, the territory of the NNP belongs to Ichnia and Parafiivka united territorial communities of Prylutsky district, Chernihiv region.

The territory of the park and its surroundings have a rich nature and ancient history, which raises the potential for the organization of recreational and tourism activities. In general, the Ichnia area has preserved numerous monuments of history and culture, which improve the potential of the Ichnia NNP' locations as sites of cultural, historical, ecological, adventure and other tourism routes.

These are mounds of the Bronze Age and the Scythian period, Chernyakhiv culture, ancient Slavic settlements, rich history of the Cossack era, architectural and park ensembles, architectural monuments, art centers and museums, including those associated with prominent artists. The historical and cultural heritage reflects the fact that the city of Ichnia in the past was a prominent center of folk arts and crafts: pottery, weaving, and embroidery. Painted ceramics of Ichnia potters in the 18th century reached a high artistic level. At the end of the 19th century Ichnia produced the best pottery in Ukraine, which was in demand far beyond the region. Ichnia tiles, unique works of folk decorative art, were especially famous. Some of them can be found in the Ichnia Museum of Local Lore.

NPP's staff interview and reports suggest that in 2020 they had just 384 visitors who participated mainly in environmental educational activities despite several ecological trails and routes designed and about 22 places furnished for temporal recreation.

The combined Canvas and SWOT template reflects generalized results of interviews, observations and surveys (Table 1). It further serves to articulate the strategic focuses of client-oriented recreation and tourism activities of Ichnia NNP as follows:

Restructuring of NNP's organizational patterns by:

- $\quad$ establishing of visit-center to perform, among others, marketing activities;

- $\quad$ initiating entrepreneurial activities to develop environmental educational, recreation and tourism activities.

Modernization of information and communication activities by using modern digital tools:

- $\quad$ to develop and implement the communication and marketing plans;

- to modernise and integrate the official web-site with travel platforms and modern messengers (Instagram, Telegram, Viber, TikTok);

- to promote the new image values in the context of recreational and tourism activities (i.e. SafeTravel, Climate and Plastic initiatives of UNWTO, some already supported by the National Tourism Organisation of Ukraine);

- $\quad$ to develop production of souvenir and promotional products.

Profiling of demand by:

- exploring the profile of NNP's visitors;

- monitoring of innovations in the market of nature tourism services;

- monitoring of innovations and exchanging experience with NNPs of Ukraine;

- determining the demand of stakeholders/partners (communities, civil society organizations, rural tourism farmsteads, tour operators, etc.). 
Table 1. Combined Canvas-SWOT design for Ichnia NPP's recreation and tourism activities

\begin{tabular}{|c|c|c|c|}
\hline Strengths & Weaknesses & Opportunities & Threats \\
\hline 1 & 2 & 3 & 4 \\
\hline \multicolumn{4}{|c|}{ CANVAS element - Consumer segments } \\
\hline $\begin{array}{l}\text { Stable segment of } \\
\text { consumers from } \\
\text { educational } \\
\text { institutions } \\
\text { different degrees }\end{array}$ & $\begin{array}{l}\text { Narrow (age, geography) } \\
\text { segment of consumers, lack of } \\
\text { defined consumer profiles, a } \\
\text { meager share of nature and } \\
\text { environment-oriented tourists } \\
\text { with various motivations for } \\
\text { travel. }\end{array}$ & $\begin{array}{l}\text { To design consumer } \\
\text { profiles, structure } \\
\text { segmentation, } \\
\text { monitor. }\end{array}$ & $\begin{array}{l}\text { General trends } \\
\text { of depopulation, } \\
\text { unfavorable } \\
\text { socio-economic } \\
\text { situation in the } \\
\text { country and the } \\
\text { region }\end{array}$ \\
\hline \multicolumn{4}{|c|}{ CANVAS element - Key values } \\
\hline $\begin{array}{lr}\text { Very rasic } \\
\text { experience of } \\
\text { services provision }\end{array}$ & $\begin{array}{l}\text { Low level of } \\
\text { - values supply correlation with } \\
\text { potential demand; integration of } \\
\text { ecologic educational activities } \\
\text { into recreational and tourism } \\
\text { services; image elements } \\
\text { exploitation; } \\
\text { - regulation of anthropogenic } \\
\text { load from spontaneous use of } \\
\text { places for short-term recreation; } \\
\text { - coordination of interests in the } \\
\text { formation of values between } \\
\text { land users; } \\
\text { - coordination of interests in the } \\
\text { values formation } \\
\text { stakeholders; } \\
\text { - supply diversification } \\
\text { (seasonal for some types of } \\
\text { activities (cycling, foreseen only } \\
\text { for students); } \\
\text { - supply of values / services for } \\
\text { people with disabilities. }\end{array}$ & 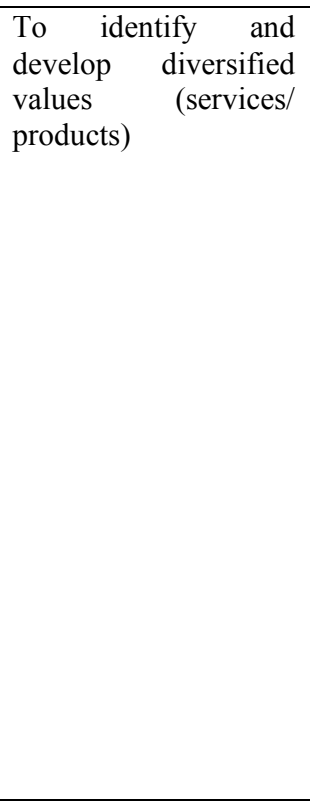 & $\begin{array}{l}\text { Low level of } \\
\text { population } \\
\text { awareness and } \\
\text { motivation, } \\
\text { inability to } \\
\text { diversify values } \\
\text { agreed with } \\
\text { stakeholders } \\
\text { due to conflicts } \\
\text { of interest and } \\
\text { due to } \\
\text { underfunding/d } \\
\text { elays in the } \\
\text { overhaul of the } \\
\text { eco-center. }\end{array}$ \\
\hline \multicolumn{4}{|c|}{ CANVAS element - Distribution/channels } \\
\hline $\begin{array}{l}\text { Some experience of } \\
\text { internet and social } \\
\text { media usage for } \\
\text { communication, } \\
\text { updating of } \\
\text { information in FB } \\
\text { (1010 followers); } \\
\text { the primary } \\
\text { information } \\
\text { infrastructure on the } \\
\text { territory }\end{array}$ & $\begin{array}{l}\text { inefficient system of } \\
\text { communication channels } \\
\text { (limited access to printed } \\
\text { materials), imperfect content of } \\
\text { the web-site, one page in one } \\
\text { social media, lack of tools for } \\
\text { feedback, visualization and } \\
\text { interactivity; imperfection of } \\
\text { information infrastructure in the } \\
\text { park; } \\
\text { lack of channels for people with } \\
\text { disabilities. }\end{array}$ & $\begin{array}{l}\text { To diversify and } \\
\text { modernise } \\
\text { communication } \\
\text { channels; to develop } \\
\text { and systematically } \\
\text { perform the } \\
\text { communication plan. }\end{array}$ & $\begin{array}{l}\text { A lack of } \\
\text { adequate ICT } \\
\text { coverage; } \\
\text { inability to } \\
\text { independently } \\
\text { diversify and } \\
\text { carry out } \\
\text { communication } \\
\text { activities; } \\
\text { inadequacy of } \\
\text { communication } \\
\text { plans and } \\
\text { actions; loss of } \\
\text { competitive } \\
\text { advantages of } \\
\text { the park. }\end{array}$ \\
\hline
\end{tabular}


Table 1. (continued)

\begin{tabular}{|c|c|c|c|}
\hline 1 & 2 & 3 & 4 \\
\hline \multicolumn{4}{|c|}{ CANVAS element - Customer relationships } \\
\hline $\begin{array}{l}\text { Developed } \\
\text { formats of direct } \\
\text { relations with } \\
\text { educational } \\
\text { institutions and } \\
\text { some local public } \\
\text { organizations }\end{array}$ & $\begin{array}{l}\text { lack of a visit center, marketing plan } \\
\text { and "automated" communication with } \\
\text { consumers; printed promotional } \\
\text { materials have any appropriate } \\
\text { marketing usage; insignificant } \\
\text { interaction with stakeholders; any } \\
\text { cross-marketing communications. }\end{array}$ & $\begin{array}{l}\text { To design and } \\
\text { implement } \\
\text { marketing plan }\end{array}$ & $\begin{array}{l}\text { institutional } \\
\text { legislative and } \\
\text { funding } \\
\text { constraints, } \\
\text { conflict of } \\
\text { interest with } \\
\text { partners; } \\
\text { erroneous } \\
\text { marketing and } \\
\text { promotional } \\
\text { campaigns. } \\
\end{array}$ \\
\hline \multicolumn{4}{|c|}{ CANVAS element - Key resources } \\
\hline $\begin{array}{l}\text { The park's natural } \\
\text { potential has no } \\
\text { alternative in the } \\
\text { northern part of } \\
\text { the Left-Bank } \\
\text { Forest-Steppe }\end{array}$ & $\begin{array}{l}\text { scattering of territories across Ichnia } \\
\text { district and mosaic patterns of the park } \\
\text { and other land users spots; remoteness } \\
\text { of places for rest and significant } \\
\text { distance to the dendrological park } \\
\text { "Trostyanets"; imperfection of } \\
\text { information, transport, infrastructure } \\
\text { and sanitary and hygienic provision; } \\
\text { the historical and cultural attractions } \\
\text { of the adjacent territory avoid } \\
\text { including NNP's locations in the } \\
\text { product; } \\
\text { lack of labor force for recreation and } \\
\text { tourism, marketing and promotion } \\
\text { activities; } \\
\text { lack of amenities for disabled people. }\end{array}$ & $\begin{array}{l}\text { To modernize the } \\
\text { potential of the } \\
\text { park resources for } \\
\text { the creation of } \\
\text { values / services of } \\
\text { modern types of } \\
\text { recreation, } \\
\text { including for } \\
\text { people } \\
\text { disabilities; with } \\
\text { integration with } \\
\text { the historical and } \\
\text { cultural heritage } \\
\text { and resources of } \\
\text { the surrounding } \\
\text { areas; digitization } \\
\text { of resources. }\end{array}$ & $\begin{array}{l}\text { further } \\
\text { deterioration of } \\
\text { the climate } \\
\text { conditions, } \\
\text { anthropogenic } \\
\text { load, pollution, } \\
\text { fire danger, lack } \\
\text { of full-fledged } \\
\text { ICT coverage; } \\
\text { lack of funding. }\end{array}$ \\
\hline \multicolumn{4}{|c|}{ CANVAS element - Key activities } \\
\hline $\begin{array}{l}\text { Operational eco- } \\
\text { center, ecological- } \\
\text { educational } \\
\text { activities, } \\
\text { supported by } \\
\text { scientific research, } \\
\text { rendering of } \\
\text { additional } \\
\text { services, } \\
\text { maintenance of } 22 \\
\text { places for short- } \\
\text { term recreation. }\end{array}$ & $\begin{array}{l}\text { A lack of a visit-center and systematic } \\
\text { activities on marketing and promotion, } \\
\text { study of demand, integration of eco- } \\
\text { educational and recreation and tourism } \\
\text { activities, participation in projects; } \\
\text { systemic partner-network interactions. }\end{array}$ & $\begin{array}{l}\text { To develop } \\
\text { organizational } \\
\text { patterns to ensure } \\
\text { the visit center, } \\
\text { marketing and } \\
\text { promotional } \\
\text { activities, } \\
\text { diversification of } \\
\text { opportunities for } \\
\text { the use of } \\
\text { resources and the } \\
\text { creation of values } \\
\text { corresponding to } \\
\text { demand; } \\
\text { interaction and use } \\
\text { of cross-marketing } \\
\text { tools in } \\
\text { partnership with } \\
\text { stakeholders. }\end{array}$ & $\begin{array}{l}\text { Inability to } \\
\text { modernize } \\
\text { activities; lack } \\
\text { or delay of } \\
\text { funding for } \\
\text { activities and } \\
\text { innovations. }\end{array}$ \\
\hline
\end{tabular}


Table 1. (continued)

\begin{tabular}{|c|c|c|c|}
\hline 1 & 2 & 3 & 4 \\
\hline \multicolumn{4}{|c|}{ CANVAS element - Key partners } \\
\hline $\begin{array}{l}\text { Strong partnership } \\
\text { with educational } \\
\text { institutions and } \\
\text { some public } \\
\text { organizations of } \\
\text { Ichnia area, some } \\
\text { experience of } \\
\text { interaction with } \\
\text { tour-operators. }\end{array}$ & $\begin{array}{l}\text { Insignificant number of strong } \\
\text { partners limited to local level entities, } \\
\text { weak relations with other nature } \\
\text { reserves of Chernihiv region / } \\
\text { Ukraine, almost no interaction with } \\
\text { stakeholders (land users, } \\
\text { communities, tour-operators, rural } \\
\text { tourism farmsteads, etc.). }\end{array}$ & $\begin{array}{l}\text { To network and } \\
\text { establish } \\
\text { collaboration, } \\
\text { cooperation and } \\
\text { long-term } \\
\text { partnerships with } \\
\text { stakeholders, } \\
\text { focused on } \\
\text { opportunities of } \\
\text { cross-marketing } \\
\text { and clustering, } \\
\text { public-private } \\
\text { partnership. }\end{array}$ & $\begin{array}{l}\text { Conflicts of } \\
\text { interest } \\
\text { (competition) } \\
\text { with } \\
\text { stakeholders/pa } \\
\text { rtners, } \\
\text { impossibility of } \\
\text { concluding } \\
\text { long-term } \\
\text { agreements, } \\
\text { fear to go } \\
\text { beyond the local } \\
\text { scale. }\end{array}$ \\
\hline \multicolumn{4}{|c|}{ CANVAS element - Costs } \\
\hline $\begin{array}{lr}\text { Fixed costs } & \text { are } \\
\text { covered } & \text { by } \\
\text { funding from the } \\
\text { state budget }\end{array}$ & $\begin{array}{l}\text { Irrational costs for obviously } \\
\text { uncompetitive products or services; } \\
\text { unstable variable costs; } \\
\text { Tiny revenue streams limit additional } \\
\text { expenses for arrangement of the } \\
\text { territory, production of souvenirs, etc. }\end{array}$ & $\begin{array}{l}\text { To generate } \\
\text { revenue streams in } \\
\text { order to cover } \\
\text { (partially) } \\
\text { maintenance and } \\
\text { activities costs. }\end{array}$ & $\begin{array}{ll}\text { A lack of } \\
\text { funding or } \\
\text { underfunding of } \\
\text { NNP. }\end{array}$ \\
\hline \multicolumn{4}{|c|}{ CANVAS element - Revenue streams } \\
\hline $\begin{array}{l}\text { Legislatively } \\
\text { provided ability to } \\
\text { independently set } \\
\text { prices for } \\
\text { recreational } \\
\text { services that the } \\
\text { national park } \\
\text { provides } \\
\text { tourists/ }\end{array}$ & $\begin{array}{l}\text { Not flexible pricing policy; limited } \\
\text { income from the existing } \\
\text { accommodation facilities for the } \\
\text { creation of values/services; any } \\
\text { sponsorship, grant and project } \\
\text { activities experience. }\end{array}$ & $\begin{array}{l}\text { To optimise } \\
\text { pricing policy, } \\
\text { revenue streams } \\
\text { through } \\
\text { diversification of } \\
\text { services and the } \\
\text { establishment of } \\
\text { strong } \\
\text { partnerships, } \\
\text { involvement into } \\
\text { project, grants and } \\
\text { sponsorship. }\end{array}$ & $\begin{array}{l}\text { inability to } \\
\text { realize } \\
\text { opportunities to } \\
\text { generate } \\
\text { revenue } \\
\text { streams, low } \\
\text { solvency of the } \\
\text { population. }\end{array}$ \\
\hline
\end{tabular}

Diversification of values for a wide range of customer segments with different travelling motivation by:

- optimising the existing and designing new trails, parking lots, routes to provide environmental educational and nature recreation and tourism services;

- modernising existing and creating new infrastructure (including temporal and permanent accommodation) for sustainable recreational and tourism activities, ensuring the safety of visitors and protection of nature;

- creating locations within NNP's territory attractive for inclusion into tourism products across the neighboring territory.

Networking with stakeholders (communities, civil society entities, tour-operators, rural farmsteads, etc.) based on public-private partnership models and usage of cross-marketing tools, including:

- identification of common interests related to the values of NNP and development of a joint action plan for the implementation of development strategies and programs; 
- participation in pilot project of regional tourism route "The Taste Routes of Chernihiv Region";

- promotion of establishment of rural tourism farmsteads in villages located within the territory of the park and neighboring areas;

- $\quad$ participation in grant programmes and projects.

\section{Conclusion}

Current challenges of national parks development in Ukraine require an appropriate recasting of their strategies to overcome outdated soviet-time management fails. Recreation and tourism activities have potential to facilitate revenue streams and can rely on employing Canvas business model combined with SWOT-analysis in design of strategy for their development. This research of Ichnia NPP presents a case study to overcome a lack of previous explorations of that kind and serve as a ground for further facts-based decisionmaking and planning.

\section{References}

1. How national parks around the world influenced sustainable tourism development. World Travel and Tourism Organization.. July (2016). URL: https://worldtraveltourismcouncil.medium.com/how-national-parks-around-theworld-influenced-sustainable-tourism-development-6e149cfc0688

2. A. Spenceley, S. McCool, D. Newsome, A. Báez, J. R. Barborak, Cl.-J. Blye, K. Bricker et al. Parks, 27 (Special issue) (2021) URL: https://parksjournal.com/wpcontent/uploads/2021/03/Spenceley_et_al10.2305-IUCN.CH_.2021.PARKS-27SIAS.en_.pdf

3. V. Mhlamian, Natsionalni parky Ukrainy: nishchivne ruynuvannia zapovidnykh zon (National parks of Ukraine: devastating destruction of protected areas), UNIAN. January (2016) URL:https://www.unian.ua/ecology/1250448-natsionalni-parkiukrajini-nischivne-ruynuvannya-zapovidnih-zon.html (In Ukrainian)

4. N. Konishcheva, S.Tkachova, Innovations and technologies in the service sphere and food industry. 2, 23-35 (2020) (In Ukrainian)

5. O.Milinchuk. Elektronnyi naukovyi zhurnal «Pryazovskyi ekonomichnyi visnyk», 5, 67-71 (2017) (In Ukrainian)

6. Yu.Onoyko, Naukovyi visnyk Khersonskoho derzhavnoho universytetu. Seriia: Heohrafichni nauky, 9, 154-157 (2018) (In Ukrainian)

7. N. Pankiv, Scientific Bulletin of UNFU, 29(5), 88-92 (2019) (In Ukrainian)

8. T. Bezsmertniuk, M. Melniichuk, Naukovi zapysky Ternopilskoho natsionalnoho pedahohichnoho universytetu imeni Volodymyra Hnatiuka. Ser. Heohrafiia. Ternopil: Taip, 1(48), 77-83 (2020) (In Ukrainian)

9. S. Korotun, M. Yakovyshyna, Visnyk NUVHP, 2(74), 163-170 (2016) (In Ukrainian)

10. S. Sahebalzamani, G. Bertella, Sustainability, 10, 1-15 (2018)

11. B. Wirtz. Business Model Management: Design, Instruments, Success Factors. Gabler: Wiesbaden, Germany (2011)

12. R. Wingit, E. Maulina, M. Rizal, M. Purnom, International Journal of Management and Administrative Sciences (IJMAS) (ISSN: 2225-7225) 4(12), 45-64 (2017) 
13. M. Perić, N. Wise, D. Dragičević, Sport, Business and Management, 7(1), 58-76 (2017)

14. M. Peric, N. Wise, Local Economy. 30, 1000-1016 (2015)

15. Mirza, International Journal of Innovative Science and Research Technology, 4, 703710 (2019)

16. R. Strulak-Wójcikiewicz, N. Wagner, A. Łapko, E. Hącia, Procedia Computer Science, 76, 1643-1651 (2020)

17. G. Richards, Journal of Hospitality and Tourism, 19(1), 1-13 (2021)

18. S. Debarliev, S. Mitrovska, European Scientific Journal, 12(35), 82-104 (2016)

19. R.Ambrož, D.G.Omerzel, Academica Turistica, 10(2), 175-183 (2017)

20. A. Osterwalder. Business Model Generation. John Wiley\&Sons, Inc, Hoboken, Ney Jersey, (2010)

21. F. R. David. Strategic Management concept and cases (13th ed). United Stated of America: Pearson Education, INc., Publishing as prentice Hall (2011) 